\title{
A Valepotriate Fraction of Valeriana glechomifolia Shows Sedative and Anxiolytic Properties and Impairs Recognition But Not Aversive Memory in Mice
}

\author{
Natasha Maurmann, ${ }^{1,2}$ Gustavo Kellermann Reolon, ${ }^{1,2}$ Sandra Beatriz Rech, ${ }^{3}$ \\ Arthur Germano Fett-Neto, ${ }^{1}$ and Rafael Roesler ${ }^{1,2}$ \\ ${ }^{1}$ Graduate Program in Cellular and Molecular Biology, Center for Biotechnology, Federal University of Rio Grande do Sul, \\ 91501970 Porto Alegre, RS, Brazil \\ ${ }^{2}$ Laboratory of Molecular Neuropharmacology, Department of Pharmacology, Institute for Basic Health Sciences, \\ Federal University of Rio Grande do Sul, Porto Alegre, Brazil \\ ${ }^{3}$ Faculty of Pharmacy, Federal University of Rio Grande do Sul, Porto Alegre, Brazil \\ Correspondence should be addressed to Natasha Maurmann, natasha.maurmann@ufrgs.br
}

Received 14 August 2009; Accepted 1 December 2009

Copyright ( $) 2011$ Natasha Maurmann et al. This is an open access article distributed under the Creative Commons Attribution License, which permits unrestricted use, distribution, and reproduction in any medium, provided the original work is properly cited.

\begin{abstract}
Plants of the genus Valeriana (Valerianaceae) are used in traditional medicine as a mild sedative, antispasmodic and tranquilizer in many countries. This study was undertaken to explore the neurobehavioral effects of systemic administration of a valepotriate extract fraction of known quantitative composition of Valeriana glechomifolia (endemic of southern Brazil) in mice. Adult animals were treated with a single intraperitoneal injection of valepotriate fraction (VF) in the concentrations of $1,3 \mathrm{or} 10 \mathrm{mg} \mathrm{kg} \mathrm{gr}^{-1}$, with vehicle in the pre-training period before each behavioral test. During the exploration of an open field, mice treated with $10 \mathrm{mg} \mathrm{kg}^{-1}$ of VF showed reduced locomotion and exploratory behavior. Although overall habituation sessions for locomotion and exploratory behavior among vehicle control and doses of VF were not affected, comparison between open-field and habituation sessions within each treatment showed that VF administration at 1 and $10 \mathrm{mg} \mathrm{kg}^{-1}$ impaired habituation. In the elevated plusmaze test, mice treated with VF $\left(10 \mathrm{mg} \mathrm{kg}^{-1}\right)$ showed a significant increase in the percentage of time spent in the open arms without significant effects in the number of total arm entries. VF at $3 \mathrm{mg} \mathrm{kg}^{-1}$ produced an impairment of novel-object recognition memory. In contrast, VF did not affect fear-related memory assessed in an inhibitory avoidance task. The results indicate that VF can have sedative effects and affect behavioral parameters related to recognition memory.
\end{abstract}

\section{Introduction}

Complementary and alternative medicines (CAMs) have a long history of use for the treatment of sleep disorders [1]. The species of Valeriana are known for medical properties that date back to many centuries [2], and the herbal supplement valerian (Valeriana officinalis) is one of the most popular CAM therapies for insomnia [3, 4].

More than 100 constituents have been identified in Valeriana sp., including sesqui and monoterpenes (hydrophilic valerenic acids and the hydrophobic valepotriates, resp.), which may account for the activity in the central nervous system [2]. Valepotriates are iridoids with a cyclopenta $(c)$ pyranoid skeleton, an epoxy ring and three ester linkages, without glycosidic linkages [5], and controversial pharmacological activity [6]; their degradation products, valtroxal, 8,9-didehydro-7-hydroxy-dolichodial, 11-ethoxyviburtinal and baldrinal may account for valerian's effect [7]. Although several clinical studies revealed sleepimprovement properties, there is no scientific agreement on the sedating mode of action or the active constituents responsible for the valerian effects $[2,3,8,9]$.

Valeriana glechomifolia Meyer is an herb that grows in a restricted area of southern Brazil, and is not currently used as a phytomedicine. This plant accumulates valepotriates, both in shoots $(1.57 \mathrm{~g} \% \mathrm{DW})$ and roots $(0.47 \mathrm{~g} \% \mathrm{DW})[10]$. As an alternative to the extraction of field-grown plants of $V$. glechomifolia for studies on pharmacological properties of 
the species, we developed in vitro propagation protocols and studied the kinetics of growth and valepotriate production in aseptically cultivated plants [11-13].

The activity of valepotriates in the central nervous system remains inconclusive and the pharmacological effects of $V$. glechomifolia have not been examined yet. Therefore, a detailed behavioral and memory analysis of the effect of a valepotriate extract fraction of known quantitative composition from this species was carried out in mice model to evaluate locomotion (open field), anxiety (elevated plus maze), aversive memory (inhibitory avoidance) and declarative memory (object recognition).

\section{Methods}

2.1. Plant Material. Valeriana glechomifolia Meyer plants were collected in the region of Aparados da Serra, near the city of São Jose dos Ausentes $\left(28^{\circ} 44^{\prime} 54^{\prime \prime}\right.$ south and $50^{\circ} 03^{\prime} 57^{\prime \prime}$ west), state of Rio Grande do Sul, Brazil, in the autumn. The species was identified by Dr M. Sobral and a voucher specimen (Sobral, 7733) is deposited at the Herbarium of the Federal University of Rio Grande do Sul (ICN). The plants were frozen, lyophilized, powdered and stored in freezer.

2.2. Preparation of Chloroform Extract of Valerian. Lyophilized shoots and roots of the plant were crushed to a particle size $<850 \mu \mathrm{m}$. Approximately $100 \mathrm{~g}$ (dry weight) was extracted twice with $500 \mathrm{~mL}$ of chloroform for $15 \mathrm{~min}$ using a sonication bath (Ultrasonic). The extract was filtered through a glass filter and evaporated to dryness in vacuum at $40^{\circ} \mathrm{C}$, yielding $4.21 \mathrm{~g}$ of extract.

2.3. Preparation of Semi-Purified Valepotriate Fraction. To further purify the valepotriate fraction (VF), the dried extract was separated by silica gel vacuum column chromatography with a hexane:chloroform gradient. The fraction containing valepotriates was monitored by preparative thinlayer chromatography (TLC) with chloroform:methanol (50:0.5) as eluent [10]. The VF was concentrated and used in the behavior tests.

2.4. Quantification of Valepotriates. High-pressure liquid chromatography (HPLC) analysis of valepotriates in the VF was performed as previously described [10]. The VF $(3 \times$ $5 \mathrm{mg}$ ) was dissolved in methanol and analyzed in a Shimadzu equipment, using a Nova-Pack C18 column and pre-column (Waters). The mobile phase was acetonitrile/water 50:50 $(\mathrm{v} / \mathrm{v})$, and the flow rate $1 \mathrm{~mL} \mathrm{~min}^{-1}$; detection was done at $208 \mathrm{~nm}$ (didrovaltrate, retention time of $19.8 \mathrm{~min}$ ) and $254 \mathrm{~nm}$ (acevaltrate, retention time of $18.1 \mathrm{~min}$ and valtrate, $34.8 \mathrm{~min}$ ) [10-14]. The valepotriates used as external standards were isolated as described elsewhere [10] and the identity and purity of the compounds were confirmed by nuclear magnetic resonance ( ${ }^{1} \mathrm{H}$ NMR) [14]. The spectral data were identical to those reported in the literature [15]. The phytochemical analysis revealed that the VF contained $96 \%$ of valepotriates ( $5 \mathrm{mg}$ of VF contained $2.05 \pm 0.11 \mathrm{mg}$ of didrovaltrate, $1.66 \pm 0.05 \mathrm{mg}$ of valtrate and $1.10 \pm 0.01 \mathrm{mg}$ of acevaltrate).

2.5. Animals. Swiss male CF1 mice (60-90 days old with mean body weight of $36.18 \pm 3.41 \mathrm{~g}$ ) obtained from the State Foundation for Production and Research in Health (FEPPS), Porto Alegre/Rio Grande do Sul/Brazil, were used in the pharmacological assays. Each group consisted of 8-10 animals, kept on a $12 \mathrm{~h}$ light/dark cycle with food and water available ad libitum. Behavioral procedures were conducted between 11 a.m. and 6 p.m. Experimental procedures were performed in accordance with the European Convention for the Protection of Vertebrate Animals Used for Experimental and Other Scientific Purposes (European Treaty SeriesNo. 170 revised 2005) and the procedures of the Brazilian College of Laboratory Animals (COBEA). The experimental protocols were approved by the institutional research ethics and animal care committee (document number GPPGHCPA 05-519). All efforts were made to minimize the number of animals and their suffering.

2.6. Drugs and Pharmacological Procedures. The VF was suspended in saline with Tween-80, 5.0\% (v/v). Fresh solutions were prepared each time and intraperitoneally injected in a volume of $10 \mathrm{~mL} \mathrm{~kg}^{-1}$ body weight at the doses of 1,3 or $10 \mathrm{mg} \mathrm{kg}^{-1}$; the control mice were injected with vehicle. A well-established positive control of elevated plus maze, diazepam intraperitoneal (i.p.) injection ( $1 \mathrm{mg} \mathrm{kg}^{-1}$, obtained from DEG Imp. de Produtos Químicos Ltda, Brazil) was also examined in this task. VF injections were given $30 \mathrm{~min}$ before the elevated plus maze and $30 \mathrm{~min}$ before each training of the behavioral test.

2.7. Open-Field Behavior. The open-field exploration was carried out as previously described [16]. The open field was a $50 \times 25 \mathrm{~cm}$ arena, surrounded by $50 \mathrm{~cm}$ high walls, and made of plywood with a frontal glass wall. The floor of the arena was divided into 12 equal squares by black lines. Animals were placed on the left rear quadrant and left to freely explore the arena for $5 \mathrm{~min}$. Latency to start locomotion, crossings of the black lines, rearings performed and the number of fecal pellets were counted. The numbers of crossings and rearings were used as measures of locomotor activity and exploratory behavior, respectively, whereas the latency to start locomotion and the number of fecal pellets were used as indicators of anxiety. After 24 hours, animals were left to explore the apparatus again for another $5 \mathrm{~min}$, and the same measures were recorded to evaluate habituation memory to the open field.

2.8. The Elevated Plus-Maze Test. The elevated plus maze used in this study was modified from Lister [17]. The apparatus, elevated $45 \mathrm{~cm}$ from the floor, consisted of two open arms $(30 \times 6 \mathrm{~cm})$ opposite to one another and crossed at right angles by two enclosed arms $(30 \times 6 \times 15 \mathrm{~cm})$ with an open roof. Anxiolytic compounds selectively increase the percentage of time spent and/or arm entries in the open arms; in contrast, anxiogenic compounds selectively decrease 
the percentage of time spent and/or arm entries in the open arms. The number of entries and the total time spent in each of the two arm types were taken during a 5-min test period after the mice had been placed in the center of the maze 30 min following VF, diazepam or vehicle administration.

2.9. Novel Object Recognition. The novel object recognition task was performed as previously described [16]. Object recognition training and test trials took place in the same arena used for the open field. After 24 hours of a 5-min arena habituation session, the mice were trained in the novel object recognition task. Training was conducted by placing individual animals for $5 \mathrm{~min}$ into the arena, in which two identical objects (objects A1 and A2; Lego Duplo toys) were positioned in two adjacent corners, $10 \mathrm{~cm}$ from the walls. In a long-term memory retention test given 24 hours after training, the same mice explored the field for $5 \mathrm{~min}$ in the presence of familiar object A1 and a novel object B. All objects presented similar textures and sizes, but distinctive colors and shapes. Exploration was defined as sniffing or touching the object with the nose and/or forepaws. The exploratory preference was defined as the percentage of the total exploration time that the animal spent investigating object A2 (in the training) or the novel object.

2.10. Inhibitory Avoidance. The step-down inhibitory avoidance apparatus and procedures were described in previous studies [16]. The inhibitory avoidance training box was a 50 $\times 25 \times 25 \mathrm{~cm}$ acrylic box whose floor consisted of parallel stainless-steel bars. A platform $(10 \times 10 \times 2 \mathrm{~cm})$ was placed on the center of the floor. In the training trial, animals were placed on the platform, and their latency to step-down on the grid with all four paws was recorded. Immediately after stepping down on the grid, animals were given a $0.6 \mathrm{~mA} / 3 \mathrm{~s}$ footshock. In the retention test session carried out 24 hours after training, no footshocks were given on test and a ceiling of $180 \mathrm{~s}$ was imposed in the test latency.

2.11. Statistical Analysis. Open field, habituation, elevated plus maze and novel object recognition data were expressed as mean \pm standard error. Data for inhibitory avoidance were expressed as median + interquartile range of stepdown latencies. Comparisons among groups were performed using one-way analysis of variance (ANOVA) followed by LSD (parametric data) or Kruskal-Wallis analysis of variance followed by Mann-Whitney $U$ (non-parametric data) tests when necessary. Comparisons between behavioral trials within the same group (comparisons between open-field behavior session and habituation session in the open-field test, comparisons between training and test sessions in the novel object recognition and in the inhibitory avoidance) were done by Wilcoxon test. $P$-values of $<.05$ were considered to indicate statistical significance. Statistical analyses were performed using the statistical software package SPSS.

\section{Results}

3.1. Open-Field Behavior and Open-Field Habituation. The results showed that there were no significant differences among groups in the latency to start locomotion in openfield sessions $(F(3,36)=2.35, P=.09$; Figure $1(\mathrm{a}))$, or number of fecal pellets $(F(3,36)=1.65, P=.20$; Figure $1(b))$. However, mice treated with VF at $10 \mathrm{mg} \mathrm{kg}^{-1}$ showed significantly lower numbers of crossings $(F(3,36)=2.95, P$ $=.046$; Figure $1(\mathrm{c}))$ and rearings $(F(3,36)=3.09, P=.039$; Figure $1(\mathrm{~d})$ ), which indicate alterations in locomotion and reduced exploratory behavior, compared with the control animals.

Results for open-field habituation session, 24 hours after the first open-field exploration session, are shown in Figure 1. There were no significant differences among groups in the latency to start locomotion $(F(3,36)=1.57, P$ $=.21$; Figure $1(\mathrm{a}))$, number of fecal pellets $(F(3,36)=2.32, P$ $=.09 ; \quad$ Figure $1(\mathrm{~b}))$, number of crossings $(F(3,36)=1.43, P$ $=.25$; Figure $1(\mathrm{c}))$ or number of rearings $(F(3,36)=1.23, P$ $=.31$; Figure $1(\mathrm{~d}))$, indicating no alterations in locomotion and reduced exploratory behavior in the habituation session, compared with the control animals.

For addressing the habituation process of the open-field experiment (Figure 1) in a more specific way, Wilcoxon tests were applied between sessions of the same treatment. These tests showed the expected significant decrease in the number of rearings during habituation session in the control mice treated with vehicle $(P=.008)$. This profile was maintained in mice that received $3 \mathrm{mg} \mathrm{kg}^{-1}$ of $\mathrm{VF}$ $(P=.038)$. However, mice treated with $1 \mathrm{mg} \mathrm{kg}^{-1}$ of $\mathrm{VF}$ showed no difference in the rearings $(P=.767)$, whereas those treated with VF $10 \mathrm{mg} \mathrm{kg}^{-1}(P=.037)$ displayed an increased number of rearings during the habituation session, indicating an impairment in the habituation process. Control mice also showed the expected significant decrease in the latency to start locomotion $(P=.036)$, a response that was not observed in any of the VF concentrations. The highest doses of VF ( 3 and $10 \mathrm{mg} \mathrm{kg}^{-1}$ ) caused mice to produce more fecal pellets $(P=.035$ and .039 , resp. $)$, indicating increased anxiety in the habituation session (24 hours after VF administration).

3.2. The Elevated Plus-Maze Test. Mice treated with $10 \mathrm{mg} \mathrm{kg}^{-1} \mathrm{VF}$ or diazepam at $1 \mathrm{mg} \mathrm{kg}^{-1}$ showed a significant increase in the percentage of time spent in the open arms when compared with control mice $(F(3,36)=2.729, P=.032$ and .014, resp.; Figure 2). In addition, animals treated with diazepam also showed increased total number of arm entries $(F(3,36)=5.31, P=.001)$, whereas the VF treatments did not affect this exploratory behavior significantly (VF 1, 3 and $10 \mathrm{mg} \mathrm{kg}^{-1} ; P=.219, .818$ and .235 , resp.). There was no significant difference among VF treatments in the number of open-arms entries on the elevated plus-maze test $(F(3,36)$ $=0.315, P=.814)$.

3.3. Novel Object Recognition. Results for the effects of the VF administration on memory assessed in the novel object recognition task are shown in Figure 3. There were no differences among groups in the total time spent exploring both objects during training $(F(3,36)=1.61, P=.21)$, indicating that all groups showed similar locomotion and 


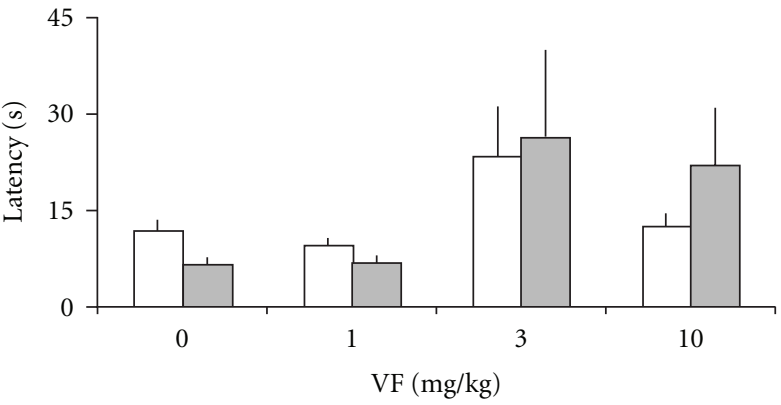

(a)

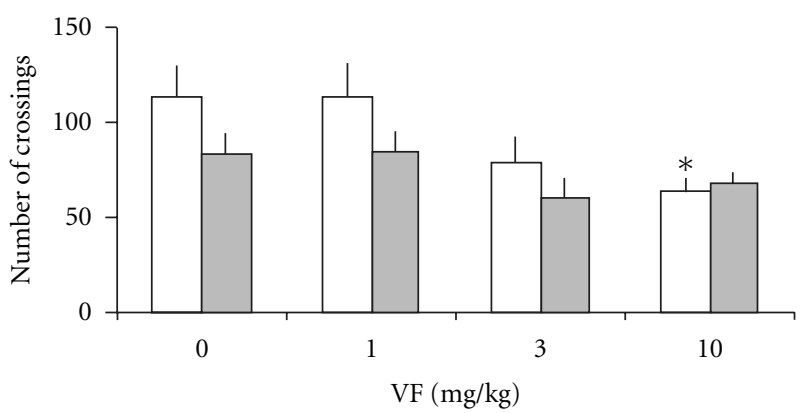

Open field session

Habituation session

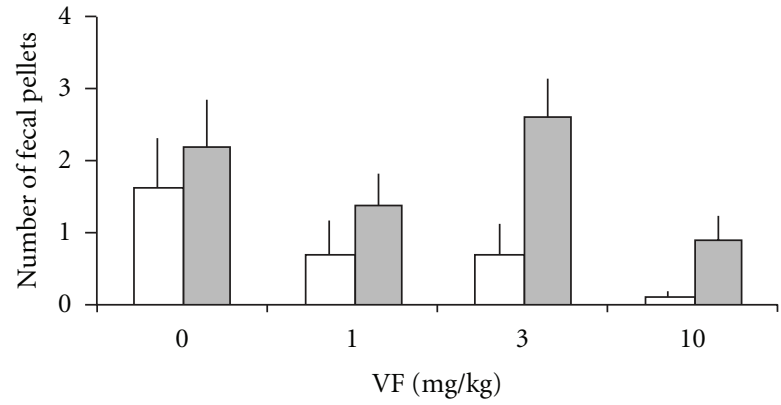

(b)

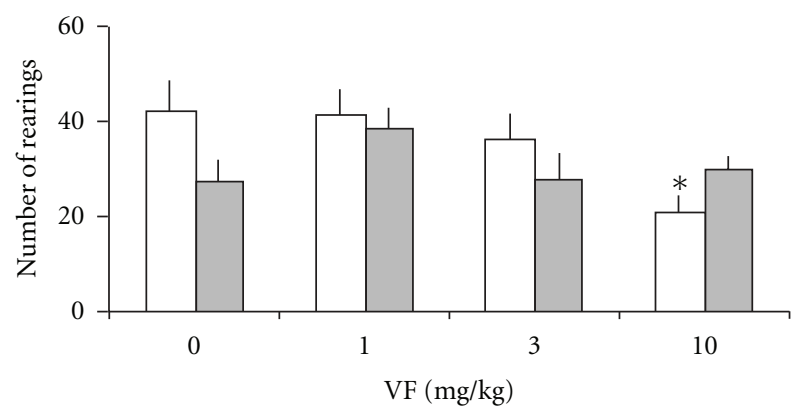

$\square$ Open field session

Habituation session

FIGURE 1: Open-field behavior and habituation in mice treated with a systemic administration of VF $\left(1,3 \mathrm{or}_{10} \mathrm{mg} \mathrm{kg}^{-1}\right)$ of V. glechomifolia $30 \mathrm{~min}$ before the first open-field exploration session. Animals were left to freely explore the arena for $5 \mathrm{~min}^{\mathrm{day}}{ }^{-1}$ during $^{2}$ days. Data are mean \pm SEM. (a) Latency to start locomotion (s), (b) number of fecal pellets, (c) number of crossings and (d) number of rearings. $n=10$ animals per group. ${ }^{*} P<.05$, significant difference from the control group.

motivation during task acquisition. Mean \pm SE total exploration time (s) was $80.9 \pm 7.2$ (control), $87.4 \pm 7.9$ (VF, $1 \mathrm{mg} \mathrm{kg}^{-1}$ ), $63.3 \pm 7.8$ (VF, $3 \mathrm{mg} \mathrm{kg}^{-1}$ ), and $70.6 \pm 11.2(\mathrm{VF}$, $\left.10 \mathrm{mg} \mathrm{kg}^{-1}\right)$. There was no significant difference between groups in exploratory preference in the training trial $(F(3,36)$ $=1.30, P=.29)$. Moreover, there was a significant difference among groups in exploratory preference during test $(F(3,36)$ $=4.37, P=.01)$. Further analysis revealed a significant difference between the control group and the group given VF at $3 \mathrm{mg} \mathrm{kg}^{-1}$ in long-term recognition memory retention tested 24 hours after training $(P=.008)$. These findings indicate that pretraining systemic administration of VF at the dose of $3 \mathrm{mg} \mathrm{kg}^{-1}$ produced an impairment of novel object recognition memory.

Wilcoxon tests showed a significantly higher novel object exploratory preference in the VF at dose of $10 \mathrm{mg} \mathrm{kg}^{-1}(P$ $=.017)$. The vehicle and VF $1 \mathrm{mg} \mathrm{kg}^{-1}$ treated group fell short of significance $(P=.069$ and .066 , resp.) and there was no significant difference among training and test at VF $3 \mathrm{mg} \mathrm{kg}^{-1}$-treated group $(P=.515)$.

3.4. Inhibitory Avoidance. Results for inhibitory avoidance are shown in Figure 4. In all groups, there were significant training-test differences (Wilcoxon test, $P<.05$ ). There were no significant differences among groups in step-down latencies in the training trial $(H=1.34, d f=3, P=.72$; mean \pm SEM overall training trial step-down latencies was 14.69 $\pm 1.65 \mathrm{~s})$. In addition, there was no significant difference between groups in long-term memory retention carried out $24 \mathrm{~h}$ after training when compared with the control group $(H$ $=0.13, d f=3, P=.99)$. The results indicate that VF did not affect inhibitory avoidance memory.

\section{Discussion}

Valeriana sp. contain several compounds including essential oils, terpenoids and small amounts of flavonoids, alkaloids and minerals $[2,5,6]$. Previous studies have reported the effect of higher polarity extracts (such as hydroalcoholic extracts) on the central nervous system $[4,6]$. Studies with non-humans tend to support valerian as a central nervous system depressant [18]. Neurobiological mechanisms have been postulated to mediate its sedative and hypnotic effects, including binding studies for gamma-amino butyric acid (GABA) [18, 19], serotononergic [8, 20], dopaminergic and noradrenergic [18] and Al adenosine [18, 21] receptors effects.

Although valerian is used traditionally as a mild sedative, research is sparse, and studies differ greatly with respect to design, measures and preparations used [22]. The role of 


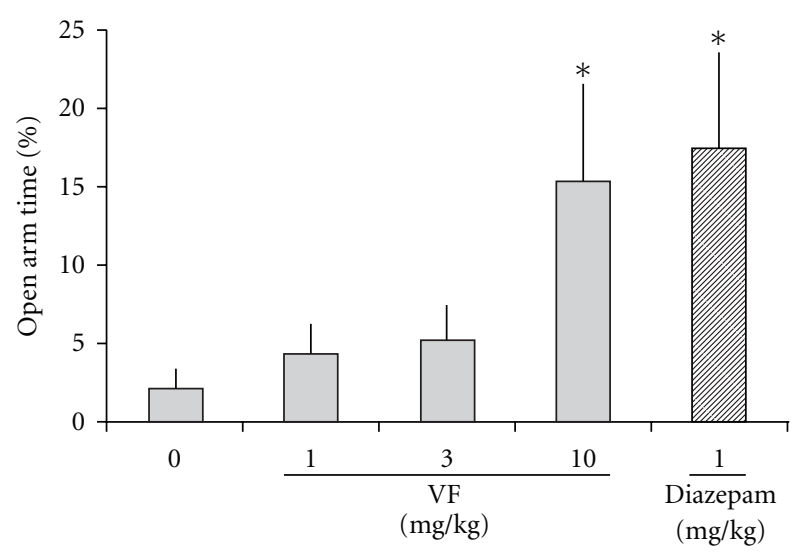

Figure 2: Elevated plus-maze behavior in mice treated with a systemic administration of VF $\left(1,3\right.$ or $\left.10 \mathrm{mg} \mathrm{kg}^{-1}\right)$ of $V$. glechomifolia $30 \mathrm{~min}$ before behavioral testing. Animals were left to freely explore the apparatus for $5 \mathrm{~min}$. The following parameter is shown: percentage open-arm time (percentage of time spent in open arms with respect to total time spent in the arms). Data are mean \pm SEM. $n=10$ animals per group. ${ }^{*} P<.05$, significant difference from the control group.

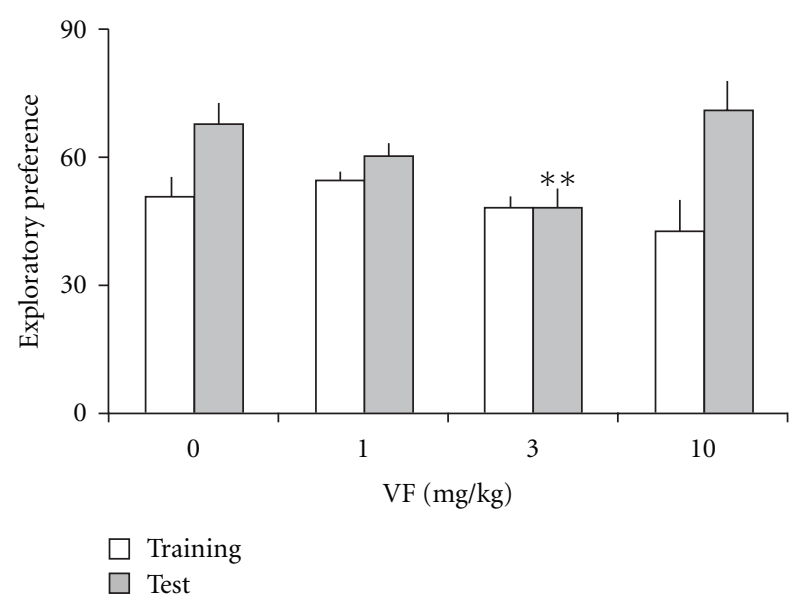

Figure 3: Novel object recognition memory in mice treated with a systemic administration of VF $\left(1,3\right.$ or $\left.10 \mathrm{mg} \mathrm{kg}^{-1}\right)$ of $V$. glechomifolia $30 \mathrm{~min}$ before the training. Memory retention was tested 24 hours after training. Data are mean \pm SEM exploratory preferences during training (light columns) or test (dark columns) trials. Exploratory preference was defined as percentage time exploring object A2 during training or percentage time exploring the novel object $\mathrm{B}$ during test trials. $n=8$ animals per group. ${ }^{* *} P<.01$, significant difference from the control group.

valepotriates is considered somewhat controversial [6]. In this study, the extract containing $96 \%$ of valepotriates of $V$. glechomifolia at $10 \mathrm{mg} \mathrm{kg}^{-1}$ was effective in reducing locomotion and exploratory behavior during open-field exploration in mice, which is indicative of sedative properties. This concentration also increased the time spent on the open arms, an indicative of anxiolytic property in the elevated plusmaze test, a well-established rodent model of anxiety [23]. However, unlike diazepam $\left(1 \mathrm{mg} \mathrm{kg}^{-1}\right)$, VF $\left(10 \mathrm{mg} \mathrm{kg}^{-1}\right)$ did not alter open-arm entries and total arm entries, but affected

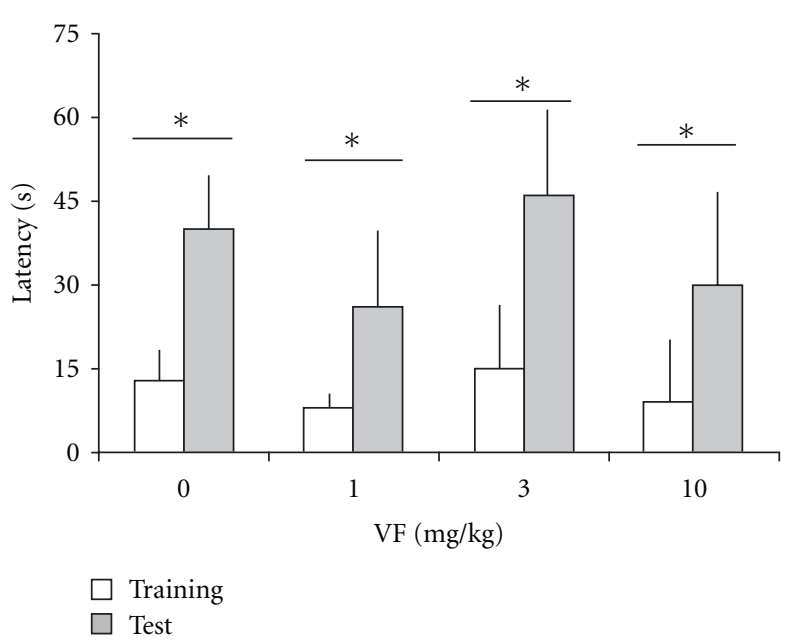

FIGURE 4: Fear-related memory assessed in an inhibitory avoidance task in mice treated with a systemic administration of $\operatorname{VF}(1,3$ or $10 \mathrm{mg} \mathrm{kg}^{-1}$ ) of $V$. glechomifolia $30 \mathrm{~min}$ before training. Memory retention was tested $24 \mathrm{~h}$ after training. Data are median + interquartile range. Latencies to step-down (s) of training (light columns) or test (dark columns). $n=9$ animals per group. There were no significant differences among groups, either in the training trial or in the test. Asterisks indicate groups showing significant training-test differences (Wilcoxon test, $P<.05$ ).

the time in closed arms. The effect is dose dependent, with lower doses of VF having no influence. Moreover, this dose did not affect the memory tests, compared with control animals. One possible interpretation for the lack of effect of VF $10 \mathrm{mg} \mathrm{kg}^{-1}$ on the number of arm entries is partial locomotion impairment as observed in Figure 1(c). However, low doses of diazepam are known to induce increase in locomotion and number of arm entries [23, 24], which may also have contributed to this result.

Neither object exploration during training in a novel object recognition task nor inhibitory avoidance performance was affected by VF, whereas $24 \mathrm{~h}$ retention of recognition memory was impaired by a lower dose of VF that did not affect locomotion or exploration. Thus, a lower dose of VF can selectively affect formation of recognition memory without inducing overt non-specific effects on other behavioral parameters.

It is interesting to note that the VF effect that impaired novel object recognition memory at the dose of $3 \mathrm{mg} \mathrm{kg}^{-1}$ was not observed at the lower $1 \mathrm{mg} \mathrm{kg}^{-1}$ and higher $10 \mathrm{mg} \mathrm{kg}^{-1}$ doses. Previous studies evaluating the effects of injections of both memory enhancing [25] and memory impairing [26] drugs on memory show that several treatments produce an inverted-U dose-response curve [27].

This is the first study, to our knowledge, that shows the neuropharmacological profile of an enriched VF from $V$. glechomifolia, and the effect of this valepotriate extract in memory. Obviously, a crude extract may have different activity due to the presence of additional compounds and interactions, which was not evaluated in the present work because the focus was on valepotriates, the major 
phytochemical components in this species. In addition, valerian-based herbal medicines are usually taken orally, an intake route through which valepotriates are poorly absorbed, even though some of their catabolites, such as baldrinal, may remain available [7]. I.p. injections as employed in the present study may considerably change bioavailability compared with oral intake, which may affect the observed activity. However, i.p. injections were used to provide homogeneous applications and to maximize bioavailability of valepotriates, the phytochemicals evaluated in this first investigation of pharmacological properties of $V$. glechomifolia.

In summary, the present study indicates that systemic administration of VF from V. glechomifolia has sedative properties and can induce alterations in recognition memory and in the elevated plus-maze behavior in mice. Further research is required to examine the neurochemical mechanisms involved in the behavioral effects.

\section{Funding}

Brazilian federal research funding organizations: Coordination of Improvement of Higher Education (CAPES Coordenação de Aperfeiçoamento de Pessoal de Nível Superior) and National Counsel of Technological and Scientific Development (CNPq - Conselho Nacional de Desenvolvimento Científico e Tecnológico).

\section{References}

[1] N. S. Gooneratne, "Complementary and alternative medicine for sleep disturbances in older adults," Clinics in Geriatric Medicine, vol. 24, no. 1, pp. 121-138, 2008.

[2] M. Blumenthal, "Valerian root," in Herbal Medicine: Expanded Commission E Monographs, M. Blumenthal, A. Goldberg, and J. Brinckmann, Eds., pp. 394-400, Integrative Medicine Communications, Newton, Mass, USA, 2000.

[3] D. M. Taibi and C. A. Landis, "Valerian and other CAM botanicals in treatment of sleep disturbances," in Complementary and Alternative Therapies and the Aging Population. An Evidence-Based Approach, R. R. Watson, Ed., pp. 57-81, Academic Press, Tucson, Ariz, USA, 2008.

[4] Sleep Disorders and CAM: At a Glace, "U.S. Department of Health and Human Services National Institutes of Health. National Center for Complementary and Alternative Medicine \# 7. 2009," November 2009, http://nccam.nih .gov/health/sleep/D437.pdf.

[5] R. Bos, H. J. Woerdenbag, F. M. S. Van Putten, H. Hendriks, and J. J. C. Scheffer, "Seasonal variation of the essential oil, valerenic acid and derivatives, and valepotriates in Valeriana officinalis roots and rhizomes, and the selection of plants suitable for phytomedicines," Planta Medica, vol. 64, no. 2, pp. 143-147, 1998.

[6] M. Marder, H. Viola, C. Wasowski, S. Fernández, J. H. Medina, and A. C. Paladini, "6-methylapigenin and hesperidin: new valeriana flavonoids with activity on the CNS," Pharmacology Biochemistry and Behavior, vol. 75, no. 3, pp. 537-545, 2003.

[7] J. Veith, G. Schneider, B. Lemmer, and M. Willems, "The effect of degradation products of valepotriates on the motor activity of light-dark synchronized mice," Planta Medica, vol. 52, pp. 179-183, 1986.
[8] B. M. Dietz, G. B. Mahady, G. F. Pauli, and N. R. Farnsworth, "Valerian extract and valerenic acid are partial agonists of the 5-HT 5a receptor in vitro," Molecular Brain Research, vol. 138, no. 2, pp. 191-197, 2005.

[9] M. Hattesohl, B. Feistel, H. Sievers, R. Lehnfeld, M. Hegger, and H. Winterhoff, "Extracts of Valeriana officinalis L. s.l. show anxiolytic and antidepressant effects but neither sedative nor myorelaxant properties," Phytomedicine, vol. 15, no. 1-2, pp. 2-15, 2008.

[10] A. L. Silva, S. B. Rech, and G. L. Von Poser, "Quantitative determination of valepotriates from Valeriana native to South Brazil," Planta Medica, vol. 68, no. 6, pp. 570-572, 2002.

[11] C. M. B. de Carvalho, N. Maurmann, D. I. Luz, A. G. FettNeto, and S. B. Rech, "Control of development and valepotriate production by auxins in micropropagated Valeriana glechomifolia," Plant Cell Reports, vol. 23, no. 4, pp. 251-255, 2004.

[12] N. Maurmann, C. M. B. De Carvalho, A. L. Silva, A. G. Fett-Neto, G. L. Von Poser, and S. B. Rech, "Valepotriates accumulation in callus, suspended cells and untransformed root cultures of Valeriana glechomifolia," In Vitro Cellular and Developmental Biology - Plant, vol. 42, no. 1, pp. 50-53, 2006.

[13] D. Russowski, N. Maurmann, S. B. Rech, and A. G. FettNeto, "Role of light and medium composition on growth and valepotriate contents in Valeriana glechomifolia whole plant liquid cultures," Plant Cell, Tissue and Organ Culture, vol. 86, no. 2, pp. 211-218, 2006.

[14] L. Salles, Phytochemical study and establishment of callus cultures of Valeriana glechomifolia Meyer (Estudo Fitoquímico e estabelecimento de culturas de calos de Valeriana glechomifolia Meyer), M.S. thesis, Pharmacy School, Federal University of Rio Grande do Sul, Rio Grande do Sul, Brazil, 1999.

[15] J Hölzl and U Koch, "The compounds of Valeriana alliariifolia. $\mathrm{I}: 1-\beta$-acevaltrate, a new valepotriate (Über die Inhaltsstoffe von Valeriana alliariifolia. I: $1-\beta$-acevaltratum, ein neues Valepotriate)," Planta Medica, vol. 50, p. 458, 1984.

[16] G. K. Reolon, L. M. Braga, M. Camassola et al., "Longterm memory for aversive training is impaired in Idua-/mice, a genetic model of mucopolysaccharidosis type I," Brain Research, vol. 1076, no. 1, pp. 225-230, 2006.

[17] R. G. Lister, "The use of a plus-maze to measure anxiety in the mouse," Psychopharmacology, vol. 92, no. 2, pp. 180-185, 1987.

[18] K. Sichardt, Z. Vissiennon, U. Koetter, A. Brattström, and K. Nieber, "Modulation of postsynaptic potentials in rat cortical neurons by valerian extracts macerated with different alcohols: involvement of adenosine A 1- and GABAA-receptors," Phytotherapy Research, vol. 21, no. 10, pp. 932-937, 2007.

[19] C.-S. Yuan, S. Mehendale, Y. Xiao, H. H. Aung, J.-T. Xie, and M. K. Ang-Lee, "The gammaminobutyric acidergic effects of valerian and valerenic acid on rat brainstem neuronal activity," Anesthesia and Analgesia, vol. 98, no. 2, pp. 353-358, 2004.

[20] C. Nencini, F. Cavallo, A. Capasso et al., "Binding studies for serotoninergic, dopaminergic and noradrenergic receptors of Valeriana adscendens Trel. extracts," Journal of Ethnopharmacology, vol. 108, no. 2, pp. 185-187, 2006.

[21] B. Schumacher, S. Scholle, J. Hölzl, N. Khudeir, S. Hess, and C. E. Müller, "Lignans isolated from Valerian: identification and characterization of a new olivil derivative with partial agonistic activity at A1 adenosine receptors," Journal of Natural Products, vol. 65, no. 10, pp. 1479-1485, 2002.

[22] S. Gutierrez, M. K. Ang-Lee, D. J. Walker, and J. P. Zacny, "Assessing subjective and psychomotor effects of the herbal 
medication valerian in healthy volunteers," Pharmacology Biochemistry and Behavior, vol. 78, no. 1, pp. 57-64, 2004.

[23] M. Rabbani, S. E. Sajjadi, and A. Mohammadi, "Evaluation of the anxiolytic effect of Nepeta persica Boiss. in mice," EvidenceBased Complementary and Alternative Medicine, vol. 5, no. 2, pp. 181-186, 2008.

[24] Y. Djeridane, B. Lemmer, and Y. Touitou, "Diazepam affects both level and amplitude of rat locomotor activity rhythm but has no effect on core body temperature," Chronobiology International, vol. 22, no. 6, pp. 975-985, 2005.

[25] J. L. McGaugh, "Dissociating learning and performance: drug and hormone enhancement of memory storage," Brain Research Bulletin, vol. 23, no. 4-5, pp. 339-345, 1989.

[26] M. G. Packard and L. A. Teather, "Double dissociation of hippocampal and dorsal-striatal memory systems by posttraining intracerebral injections of 2-amino-5-phosphonopentanoic acid," Behavioral Neuroscience, vol. 111, no. 3, pp. 543-551, 1997.

[27] R. Roesler, M. I. Kopschina, R. M. Rosa, J. A. P. Henriques, D. O. Souza, and G. Schwartsmann, "RC-3095, a bombesin/gastrin-releasing peptide receptor antagonist, impairs aversive but not recognition memory in rats," European Journal of Pharmacology, vol. 486, no. 1, pp. 35-41, 2004. 


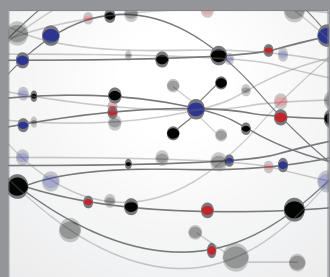

The Scientific World Journal
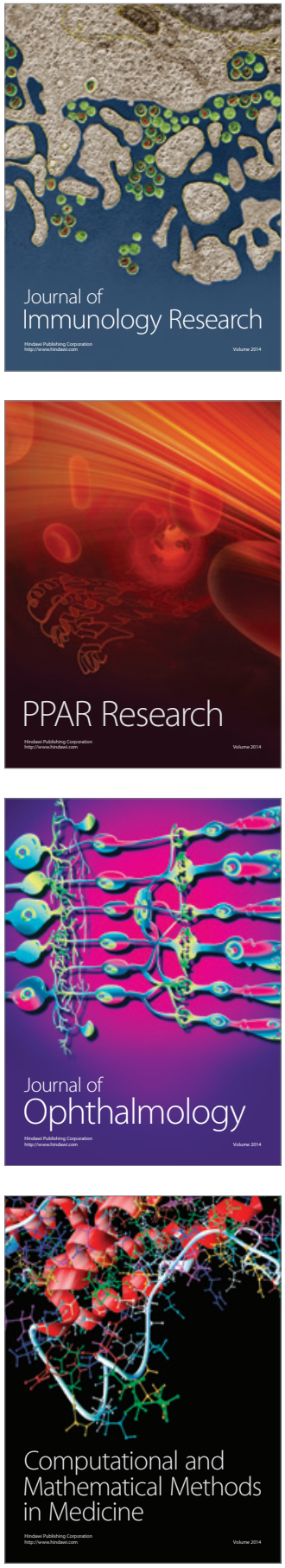

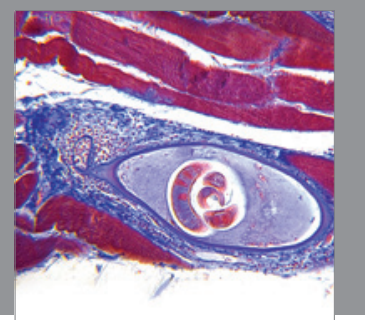

Gastroenterology

Research and Practice
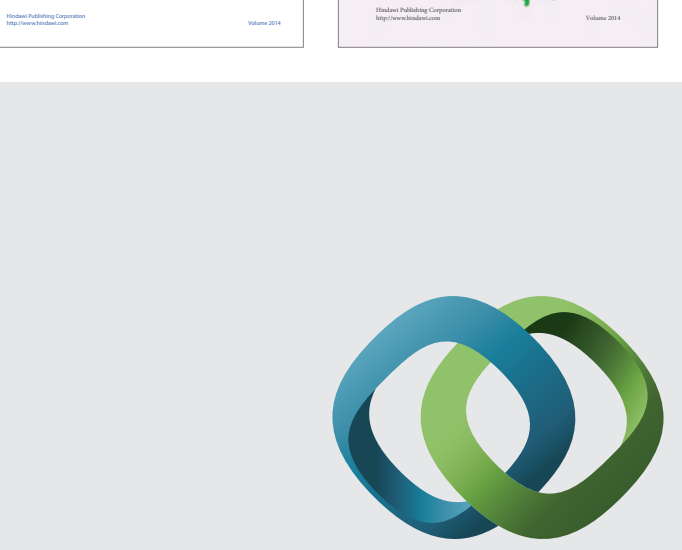

\section{Hindawi}

Submit your manuscripts at

http://www.hindawi.com
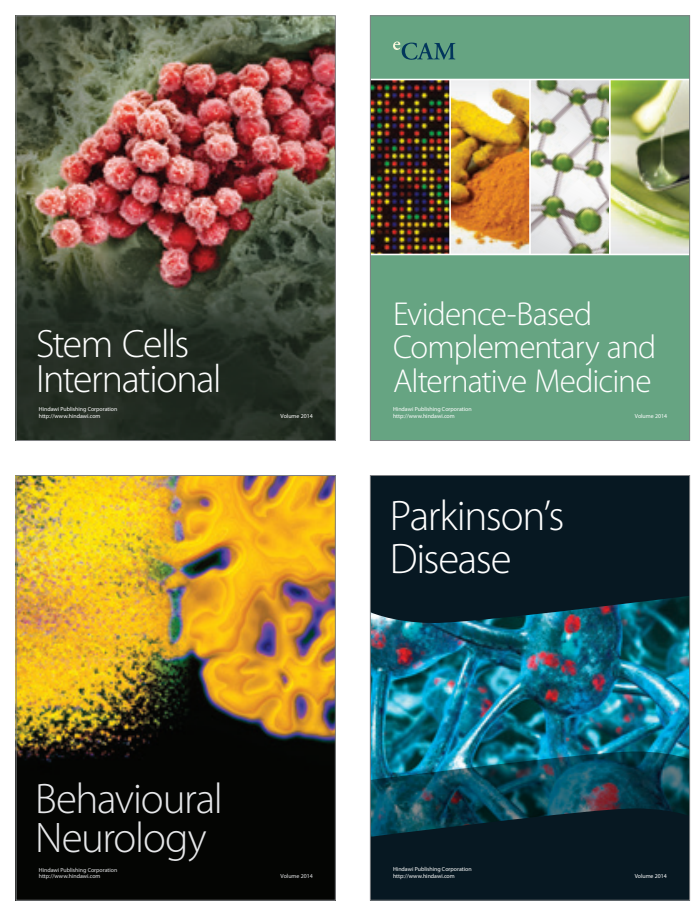

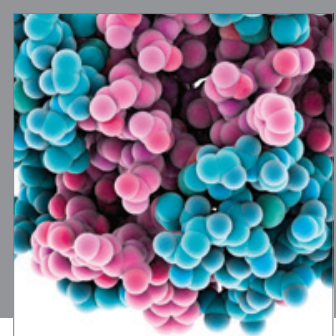

Journal of
Diabetes Research

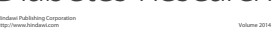

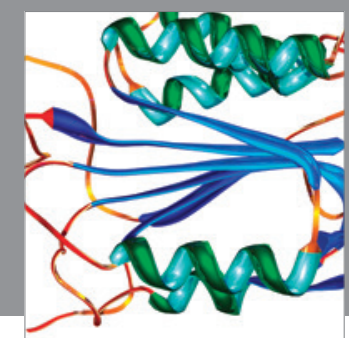

Disease Markers
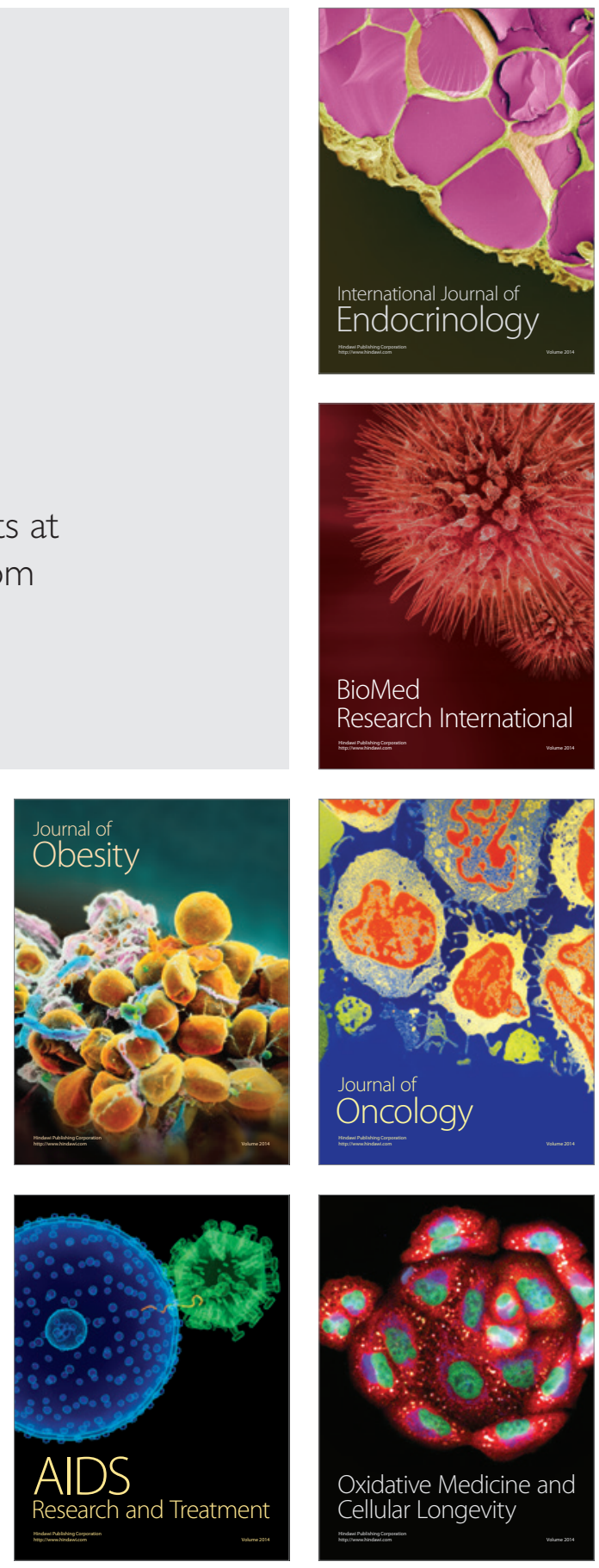